\title{
Energy Content Estimation of Municipal Solid Waste by Physical Composition in Al-Diwaniyah City, Iraq
}

\author{
Hussein Janna ${ }^{1 *}$, Mukhtar D. Abbas², Marwah M. Al-Khuzaie ${ }^{1}$, Nadhir Al-Ansari ${ }^{3}$ \\ 1 Civil Engineering Department, College of Engineering, University of Al Qadisiyah, Al-Qadisiyah, Iraq \\ 2 Ministry of Environment - Environment Directorate of Al-Qadisiyah, Iraq \\ 3 Department of Civil, Environmental and Natural Resources Engineering, Lulea University, Luleå, Sweden \\ Correspodnig author's email: hussein.janna@qu.edu.iq
}

\begin{abstract}
This study was undertaken to estimate the energy potential of municipal solid waste via creating a relationship between the high heating value (HHV) and the fractions of physical composition of municipal solid waste MSW ( $\%$ food, $\%$ plastic, $\%$ paper, $\%$ wood, $\%$ textile) into the two scenarios, namely wet MSW (as discarded) and dry (free moisture). The created models were determined based on the results of obtained from the analysis of the components of the Al-Diwaniyah MSW and then from previous studies which involved experimental ultimate analysis $(\% \mathrm{C}, \% \mathrm{O}, \% \mathrm{H}, \% \mathrm{~N}, \% \mathrm{~S})$ of $\mathrm{MSW}$, supported by the equations and models of previous studies which were used for HHV calculation. SPSS Statistical software was used to prepare the models. For each scenario, the input datasets were 60 cases, taking into account the minimization of the data and the average of HHV that result from equations. Four models were created, two models for each status where $\mathrm{R}^{2}$ was 1.00 and 0.999 for dry and wet situation, respectively. However, the equations of verification process showed that the models which depended on the dry fractions are more accurate. The produced HHV from the dry and wet MSW components in the Al-Diwaniyah City is $8655 \mathrm{KJ} / \mathrm{Kg}$ and $6440 \mathrm{KJ} / \mathrm{Kg}$, respectively (as discarded).
\end{abstract}

Keywords: municipal solid waste, energy content, high heating value models, waste characterization, landfilling.

\section{INTRODUCTION}

Generally, municipal solid waste (MSW) is a mixture of commercial and household refuse which is produced from the living community (Nagarajan, T et al. 2010).

MSW may comprise from non-degradable materials such as (metals, rubbers, leather, plastics and glass), as well as partially degradable (wood and disposable napkins) and degradable materials such as (food waste, paper, and garden waste) (Gupta, Yadav et al. 2015). The municipal solid waste varies in terms of its quantity and composition depending on seasonal variation, food habits, cultural practice, method and frequency of waste collection, ragpickers' activity and burning of waste (Kumar, Mondal et al. 2004). In addition, the awareness on waste reduction and the level of waste segregation, are other factors that may affect the waste composition (Siddiqui, Zaidi et al. 2017)

In 2016, the MSW generation was 2.1 billion metric tons globally, and is expected to increase by $70 \%$ from the 2016 levels up to 3.4 billion metric tons in 2050 (Group 2021). Currently, the generated quantity of municipal solid waste (MSW) in the Al-Diwaniyah city is about (350) tons per day and all these quantities are discarded in an open dump. Accumulation of MSW over many years causes environmental and health problems such as air pollution that is produced from burning processes, as well as soil and ground water contamination that result from the leachate. One of the optimal mechanisms in the concept of MSW management is $4 \mathrm{R}$ (reduce, reuse, recycle and recovery). MSW recycling is the only mechanism adapted by ragpickers to recycle some of the plastic, aluminum, paper and carton. Recycling is 
a cheap and easy procedure for saving resource and money and also reducing pollution (AbdelShafy and Mansour 2018).

Recovery of MSW has many patterns such as the compost which transforms the biodegradable components into fertilizer by many technological processes for soil enrichment with organic materials for agricultural purposes, and thermochemical treatment which contains gasification, pyrolysis and incineration. (Scarlat, Motola et al. 2015).

Incineration is one of the technologies used to deal with MSW where it decreases the waste volume by $(80-90) \%$ and the weight by $(70-$ 75) \% (Lopes, Okamura et al. 2015, Abdel-Shafy and Mansour 2018). However, improper incineration should be avoided to prevent the emission of toxic gases such as dioxins that result from plastic incineration (Lopes, Okamura et al. 2015). In addition to the main goal of incineration, which is minimizing the wastes, incineration can be used to produce energy, where the heating energy resulting from waste components combustion is recovered for operation of electricity stations or heating purposes. The components of the MSW can considerably affect the high heating value HHV where the MSW that have a high percentage of plastic and rubber gives HHV higher than the MSW with high percentage of food due to the chemical characteristic of components (Zhou, Meng et al. 2014).

There are some theoretical mechanisms to calculate HHV from MSW, the most effective one is the ultimate analysis. This mechanism depends on the elemental analysis for each component of MSW that concludes the percentage of $(\mathrm{C} \%, \mathrm{O} \%, \mathrm{H} \%, \mathrm{~N} \%, \mathrm{~S} \%$ and $\mathrm{Cl} \%$ ) (Antonopoulos, Karagiannidis et al. 2011, Zhou, Meng et al. 2014, Olatunji, Akinlabi et al. 2019). Depending on these chemical characteristics and by using the equations and models that predict HHV, the wellknown equations in this mechanism were Dulong, Modified Dulnog and Vandralek (Nzihou, Hamidou et al. 2014).

The second mechanism for HHV calculation is the approximate analysis which depends on the percentages of moisture $\%$, volatile matters $\%$, fixed carbon\% and ash\%) (Abu-Qudais and AbuQdais 2000, Omari 2015, Durogbitan 2019)]. Moreover, there is another method in the literature that predicts the HHV value of MSW by using many equations and models, which depends on the physical composition percentage (food $\%$, plastic $\%$, rubber $\%$, paper $\%$, textile $\%$, wood $\%$, etc. and the moisture content $\%$ ) (Liu, Paode et al. 1996, Abu-Qudais and Abu-Qdais 2000, Leme, Rocha et al. 2014).

Many other studies have been conducted to determine the mathematical models for predicting HHV depending on the ultimate analysis, such as: (Kathiravale, Muhd Yunus et al. 2003), (Meraz, Oropeza et al. 2002), (Akkaya and Demir 2009), (Ryu 2010), and (Ibikunle, Titiladunayo et al. 2019). On the other hand, the researchers who obtained the mathematical models via the approximate analysis are:(Huda 2014),(Kwaghger 2017) and (Acikkar and Sivrikaya 2018). In addition, there are mathematical models created via using the percentages of physical components to calculate the HHV such as the work by (Kathiravale, Muhd Yunus et al. 2003), (Chang, Lin et al. 2007), (Ch, Ogwueleka et al. 2012), (Leme, Rocha et al. 2014), (Lin, Wang et al. 2015)] and (Khuriati, Setiabudi et al. 2015).

The objective of this study was to determine a mathematical model that links between the high heating value HHV and the physical composition of MSW directly via using SPSS software with multiple regressions in accordance to the experimental data from previous studies.

\section{METHODOLOGY}

In order to calculate HHV via the ultimate analysis approach, three requirements need to be known:

- The percentage of each component of MSW.

- The water content percentage of the food waste

- The percentage of elemental analysis for each component of MSW.

- The relationship between HHV and the values of the elemental analysis.

\section{Determination of MSW Characteristics}

The Al-Diwaniyah City which is located in the middle south of Iraq (about $180 \mathrm{~km}$ south of Baghdad) and has a population of around 400 thousand with an average temperature ranging from $35^{\circ} \mathrm{C}$ in summer to $10^{\circ} \mathrm{C}$ in winter and the agricultural area corresponds to more than $56 \%$ of its area. Municipal solid waste (MSW) in the city is about (350) tones 
per day, and all these quantities are discarded in an open dump (Abbas, Falih et al. 2020). In order to find the percentage of physical components of Al-Diwaniyah MSW, a separation of the Al-Diwaniyah municipal waste was achieved and it was found that it consists of about ( $60 \%$ food, $10 \%$ plastic, $6 \%$ paper, $3 \%$ wood, $3 \%$ textile and $18 \%$ other), whereas the moisture content of food is $70 \%$. The percentage of the physical components of MSW in AlDiwaniyah are shown in Figure 1. The water contents of the food waste were calculated in the laboratory of Al-Diwaniyah Environment authority and it was found at a percentage of $65 \%$. However, in order to cover a wide range of the water content percentages, five percentages were used in the modeling.

The elemental analysis (chemical characteristic) of the MSW can be represented by the percentage of Carbon, Hydrogen, Oxygen, Nitrogen, and Sulfate. The percentages of these elements were obtained from previous experimental studies. The average values and the standard deviation from previous studies of each element from each component of the MSW are shown in Table 1. These percentages were used for determination of HHV for each physical component of MSW.

\section{The Input Data}

In the ultimate analysis, the values of HHV depends on the chemical characteristic and on the percentage of physical composition of MSW; therefore, they were used in different assumptions of the percentage to simulate the heterogeneity in MSW, where the physical composition changes according to the season, source of MSW (agricultural, residential and commercial) and moisture content. Sixty trials were performed. These physical compositions result from utilization of five food moisture content values $(75 \%, 70 \%$, $65 \%, 60 \%, 55 \%$ ) for each trial of the twelve ratios of physical compositions as shown in the Table.2.

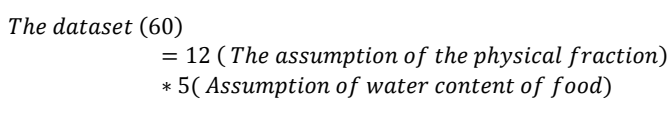

There are two types of physical fractions data of MSW, dry and wet (as discarded).

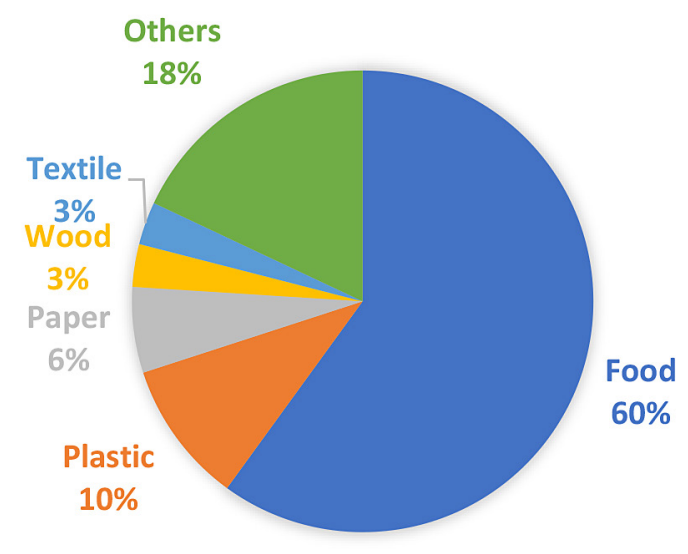

Fig. 1. The Physical Components of MSW of Al-Diwaniyah City.

Table 1. The chemical characteristics of MSW (Chai and Zakaria 2006, Gidarakos, Havas et al. 2006, Ryu 2010, Antonopoulos, Karagiannidis et al. 2011, Zhou, Meng et al. 2014, Lopes, Okamura et al. 2015, Khuriati, Budi et al. 2017)

\begin{tabular}{|c|c|c|c|c|c|c|c|c|c|c|}
\hline \multirow{2}{*}{ Element } & \multicolumn{2}{|c|}{ Food } & \multicolumn{2}{|c|}{ Plastic } & \multicolumn{2}{|c|}{ Paper } & \multicolumn{2}{|c|}{ Wood } & \multicolumn{2}{|c|}{ Textile } \\
\hline & Avg. & Stdev. & Avg. & Stdev. & Avg. & Stdev. & Avg. & Stdev. & Avg. & Stdev \\
\hline$\% \mathrm{C}$ & 41.6 & 3.2 & 73.7 & 10.0 & 44.0 & 4.0 & 47.7 & 2.0 & 52.6 & 5.0 \\
\hline$\% \mathrm{H}$ & 6.6 & 1.0 & 10.2 & 4.0 & 6.7 & 1.0 & 6.7 & 1.0 & 6.0 & 0.0 \\
\hline$\% \mathrm{~N}$ & 1.9 & 0.9 & 0.2 & 0.0 & 0.7 & 1.0 & 1.2 & 2.0 & 2.5 & 3.0 \\
\hline$\% O$ & 41.4 & 6.5 & 11.8 & 12.0 & 41.0 & 4.0 & 39.7 & 6.0 & 33.1 & 8.0 \\
\hline$\% \mathrm{~S}$ & 1.8 & 0.2 & 0.1 & 0.0 & 0.2 & 0.0 & 0.2 & 0.0 & 0.2 & 0.0 \\
\hline
\end{tabular}


Table 2. Physical composition of Dry MSW [assumed by the author]

\begin{tabular}{|c|c|c|c|c|c|c|c|c|c|c|}
\hline \multirow{3}{*}{ Composition } & \multirow{3}{*}{ Food \% } & \multirow{3}{*}{ Plastic \% } & \multirow{3}{*}{ Paper \% } & \multirow{3}{*}{ Wood \% } & \multirow{3}{*}{ Textile \% } & \multirow{2}{*}{\multicolumn{5}{|c|}{$\frac{\text { Percentage water content of food (wt) }}{\text { Assumptions }}$}} \\
\hline & & & & & & & & & & \\
\hline & & & & & & 1 & 2 & 3 & 4 & 5 \\
\hline Assumption. 1 & $50 *(1-w t)$ & 14.21 & 8.27 & 3.96 & 3.96 & \multirow{12}{*}{$75 \%$} & \multirow{12}{*}{$70 \%$} & \multirow{12}{*}{$65 \%$} & \multirow{12}{*}{$60 \%$} & \multirow{12}{*}{$55 \%$} \\
\hline Assumption. 2 & $55^{*}(1-w t)$ & 12.25 & 7.13 & 3.15 & 3.15 & & & & & \\
\hline Assumption. 3 & $60 *(1-w t)$ & 9.8 & 5.7 & 2.7 & 2.7 & & & & & \\
\hline Assumption. 4 & $65^{*}(1-w t)$ & 7.6 & 4.32 & 2.12 & 2.12 & & & & & \\
\hline Assumption. 5 & $70 *(1-w t)$ & 5.39 & 3.14 & 1.44 & 1.44 & & & & & \\
\hline Assumption. 6 & $50 *(1-w t)$ & 19.6 & 5.7 & 2.7 & 2.7 & & & & & \\
\hline Assumption. 7 & $50 *(1-w t)$ & 9.8 & 15.2 & 2.7 & 2.7 & & & & & \\
\hline Assumption. 8 & $50^{*}(1-w t)$ & 9.8 & 5.7 & 7.2 & 7.2 & & & & & \\
\hline Assumption. 9 & $50 *(1-w t)$ & 9.8 & 5.7 & 2.7 & 11.7 & & & & & \\
\hline Assumption. 10 & $50 *(1-w t)$ & 9.8 & 5.7 & 11.7 & 2.7 & & & & & \\
\hline Assumption. 11 & $50 *(1-w t)$ & 24.99 & 3.14 & 1.44 & 1.44 & & & & & \\
\hline Assumption. 12 & $50^{*}(1-w t)$ & 5.39 & 22.14 & 1.44 & 1.44 & & & & & \\
\hline
\end{tabular}

Table 2 shows the values of dry physical fractions of MSW which were applied for the equations listed in the first group (Dry) in Table 4 for calculating HHV.

Table 3 illustrates the fractions of wet MSW; these data were used in the second group of models in the Table 4 which were designed for calculating the high heating value HHV from wet MSW.

\section{Models and Equations}

The third step in this study involved two groups of models and equations. Dealing with MSW as dried and also as wet MSW as its discarded. These equations and models from previous practical studies correlate between HHV and ultimate (elemental) analysis.

\section{RESULTS AND DISCUSSIONS}

The assumed assumptions (12 assumptions) for each dry and wet physical component are shown in Tables 2 and 3, respectively, and the assumptions of the percentage of water content in the food waste (5 assumptions) are shown in Tables 2 and 3. Therefore, there are 60 values for HHV resulting from each single equation of Table 4 . This leads to computing 540 values for HHV resulting from the dry MSW (Group 1) in table 4 and 360 values for HHV resulting from wet MSW resulted from the equations of the group 2 in Table 4. In order to create the model, two methods were used, (stepwise method and enter method). In, from each of these two methods (stepwise method and enter method), two models were created (with constant

Table 3. Physical composition of Wet MSW [assumed by the author]

\begin{tabular}{|c|c|c|c|c|c|c|c|c|c|c|}
\hline \multirow{3}{*}{0,5} & \multirow{3}{*}{ Food \% } & \multirow{3}{*}{ Plastic \% } & \multirow{3}{*}{ Paper \% } & \multirow{3}{*}{ Wood \% } & \multirow{3}{*}{ Textile \% } & \multirow{2}{*}{\multicolumn{5}{|c|}{$\begin{array}{c}\text { Percentage water content of food (wt) } \\
\text { Assumptions }\end{array}$}} \\
\hline & & & & & & & & & & \\
\hline & & & & & & 1 & 2 & 3 & 4 & 5 \\
\hline Assumption. 1 & 50 & 14.5 & 8.7 & 4.4 & 4.4 & \multirow{12}{*}{$75 \%$} & \multirow{12}{*}{$70 \%$} & \multirow{12}{*}{$65 \%$} & \multirow{12}{*}{$60 \%$} & \multirow{12}{*}{$55 \%$} \\
\hline Assumption. 2 & 55 & 12.5 & 7.5 & 3.5 & 3.5 & & & & & \\
\hline Assumption. 3 & 60 & 10 & 6 & 3 & 3 & & & & & \\
\hline Assumption. 4 & 65 & 7.75 & 4.55 & 2.35 & 2.35 & & & & & \\
\hline Assumption. 5 & 70 & 5.5 & 3.3 & 1.6 & 1.6 & & & & & \\
\hline Assumption. 6 & 50 & 20 & 6 & 3 & 3 & & & & & \\
\hline Assumption. 7 & 50 & 10 & 16 & 3 & 3 & & & & & \\
\hline Assumption. 8 & 50 & 10 & 6 & 8 & 8 & & & & & \\
\hline Assumption. 9 & 50 & 10 & 6 & 3 & 13 & & & & & \\
\hline Assumption. 10 & 50 & 10 & 6 & 13 & 3 & & & & & \\
\hline Assumption. 11 & 50 & 25.5 & 3.3 & 1.6 & 1.6 & & & & & \\
\hline Assumption. 12 & 50 & 5.5 & 23.3 & 1.6 & 1.6 & & & & & \\
\hline
\end{tabular}


Table 4. Equations and models that depend on the ultimate analysis.

\begin{tabular}{|c|c|c|c|c|c|}
\hline Status & No. & Models and equations & Unit & Modeler & Reference \\
\hline \multirow{9}{*}{ 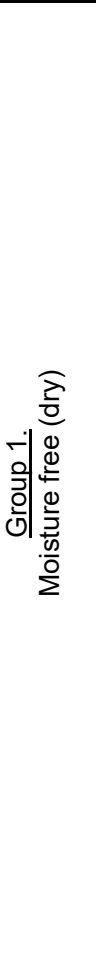 } & 1 & $\begin{array}{c}\mathrm{HHV}=81 \mathrm{C}+342.5(\mathrm{H}-\mathrm{O} / 8) \\
+22.5 \mathrm{~S}\end{array}$ & $\mathrm{KCal} / \mathrm{Kg}$ & Dulong & $\begin{array}{c}\text { (Liu, Paode et al. 1996, Kathiravale, } \\
\text { Muhd Yunus et al. 2003, Ch, Ogwueleka } \\
\text { et al. 2012, Bousdira, Nouri et al. 2014, } \\
\text { Nzihou, Hamidou et al. 2014, Khuriati, } \\
\text { Budi et al. 2017) }\end{array}$ \\
\hline & 2 & $\begin{aligned} \mathrm{HHV}= & 80.5 \mathrm{C}+338.6 \mathrm{H}-42.3 \mathrm{O} \\
& +22.2 \mathrm{~S}+5.55 \mathrm{~N}\end{aligned}$ & $\mathrm{KCal} / \mathrm{Kg}$ & Modified Dulong & $\begin{array}{c}\text { (Liu, Paode et al. 1996, Kathiravale, } \\
\text { Muhd Yunus et al. 2003, Gidarakos, } \\
\text { Havas et al. 2006, Basnayake, } \\
\text { Boyagoda et al. 2007, Ch, Ogwueleka } \\
\text { et al. 2012) }\end{array}$ \\
\hline & 3 & $\begin{array}{l}\mathrm{HHV}=81\left(\mathrm{C}-\frac{3}{8} \mathrm{O}\right)+57 \cdot\left(\frac{3}{8} \mathrm{O}\right) \\
+345\left(\mathrm{H}-\frac{\mathrm{O}}{16}\right)+25 \mathrm{~S}-6(9 \mathrm{H}+\mathrm{W})\end{array}$ & $\mathrm{KCal} / \mathrm{Kg}$ & Steuer's & $\begin{array}{l}\text { (Liu, Paode et al. 1996, Kathiravale, } \\
\text { Muhd Yunus et al. 2003, Ch, Ogwueleka } \\
\text { et al. 2012, Khuriati, Budi et al. 2017) }\end{array}$ \\
\hline & 4 & $\begin{array}{c}\mathrm{HHV}=81\left(\mathrm{C}-\frac{3}{4} \mathrm{O}\right)+342.5 \mathrm{H} \\
+22.5 \mathrm{~S}+57\left(\frac{3}{4} \mathrm{O}\right)-6(9 \mathrm{H}+\mathrm{W})\end{array}$ & $\mathrm{KCal} / \mathrm{Kg}$ & Scheurer\&Kestner's & $\begin{array}{c}\text { (Liu, Paode et al. 1996, Kathiravale, } \\
\text { Muhd Yunus et al. 2003, Bousdira, Nouri } \\
\text { et al. 2014, Nzihou, Hamidou et al. 2014, } \\
\text { Khuriati, Budi et al. 2017) }\end{array}$ \\
\hline & 5 & $\mathrm{HHV}=85 \mathrm{C}+270 \mathrm{H}+26(\mathrm{~S}-\mathrm{O})$ & $\mathrm{KCal} / \mathrm{Kg}$ & Vandralek & $\begin{array}{c}\text { (Kathiravale, Muhd Yunus et al. 2003, } \\
\text { Bousdira, Nouri et al. 2014, Nzihou, } \\
\text { Hamidou et al. 2014) }\end{array}$ \\
\hline & 6 & $\begin{array}{c}\mathrm{HHV}=0.3517 \mathrm{C}+1.1626 \mathrm{H} \\
-0.1047 \mathrm{~S}-0.1110\end{array}$ & $\mathrm{MJ} / \mathrm{Kg}$ & Boie & (Olatunji, Akinlabi et al. 2019) \\
\hline & 7 & $\begin{aligned} \mathrm{HHV}= & -2762.68+114.63 \mathrm{C} \\
& +310.55 \mathrm{H}\end{aligned}$ & $\mathrm{KCal} / \mathrm{Kg}$ & Khuriati et al., & (Khuriati, Budi et al. 2017) \\
\hline & 8 & $\begin{array}{c}\mathrm{HHV}=416.638 \mathrm{C}-570.01 \mathrm{H}+ \\
259.0310+598.955 \mathrm{~N}-5829.078\end{array}$ & $(\mathrm{KJ} / \mathrm{Kg})$ & Kathiravale et al, & $\begin{array}{c}\text { (Kathiravale, Muhd Yunus et al. 2003, } \\
\text { Khuriati, Budi et al. 2017) }\end{array}$ \\
\hline & 9 & $\begin{aligned} \mathrm{HHV} & =0.349 \mathrm{C}+1.01 \mathrm{H}-0.174 \mathrm{~N} \\
& +0.886 \mathrm{~S}-0.0812 \mathrm{O}\end{aligned}$ & $\mathrm{MJ} / \mathrm{Kg}$ & Shi et al.. & (Khuriati, Budi et al. 2017) \\
\hline \multirow{6}{*}{ 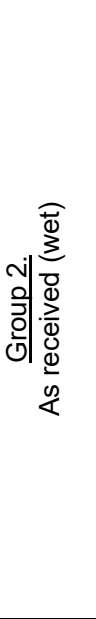 } & 1 & $\begin{array}{c}\mathrm{HHV}=\left(1-0.1 \mathrm{H}_{2} \mathrm{O}\right) \cdot(0.327 \mathrm{C} \\
+1.241 \mathrm{H}-0.089 \mathrm{O}-0.26 \mathrm{~N} \\
+0.074 \mathrm{~S})\end{array}$ & $\mathrm{MJ} / \mathrm{Kg}$ & $\begin{array}{l}\text { Akkaya and Demir, } \\
2009\end{array}$ & $\begin{array}{c}\text { (Akkaya and Demir 2009, Khuriati, Budi } \\
\text { et al. 2017) }\end{array}$ \\
\hline & 2 & $\begin{array}{c}\mathrm{HHV}=\left(1-0.1 \mathrm{H}_{2} \mathrm{O}\right) \cdot(-0.3708 \mathrm{C}- \\
1.1123 \mathrm{H}+0.13910+0.3178 \mathrm{~N} \\
-0.1391 \mathrm{~S})\end{array}$ & $\mathrm{MJ} / \mathrm{Kg}$ & Meraz et al, & $\begin{array}{c}\text { (Meraz, Domínguez et al. 2003, Abidoye } \\
\text { and Mahdi 2014, Olatunji, Akinlabi } \\
\text { et al. 2019) }\end{array}$ \\
\hline & 3 & $\begin{array}{c}\mathrm{HHV}=\left(1-0.1 \mathrm{H}_{2} \mathrm{O}\right) \cdot(-0.3517 \mathrm{C}- \\
1.1625 \mathrm{H}+0.1109 \mathrm{O}+0.0242 \mathrm{~N} \\
-0.0928 \mathrm{~S})\end{array}$ & $\mathrm{MJ} / \mathrm{Kg}$ & Meraz et al, & (Khuriati, Budi et al. 2017) \\
\hline & 4 & $\begin{array}{c}\mathrm{HHV}=\left(1-0.1 \mathrm{H}_{2} \mathrm{O}\right) \cdot(-0.3279 \mathrm{C}- \\
1.5330 \mathrm{H}+0.1668 \mathrm{O}-0.0242 \mathrm{~N}- \\
0.0928 \mathrm{~S})\end{array}$ & $\mathrm{MJ} / \mathrm{Kg}$ & Wilson & $\begin{array}{l}\text { (Meraz, Oropeza et al. 2002, Meraz, } \\
\text { Domínguez et al. 2003, Abidoye and } \\
\text { Mahdi 2014, Olatunji, Akinlabi et al. 2019) }\end{array}$ \\
\hline & 5 & $\begin{array}{c}\mathrm{HHV}=\left(1-0.1 \mathrm{H}_{2} \mathrm{O}\right) \cdot(-0.3578 \mathrm{C}- \\
1.1357 \mathrm{H}+0.0845 \mathrm{O}-0.0594 \mathrm{~N}- \\
0.1119 \mathrm{~S})\end{array}$ & $\mathrm{MJ} / \mathrm{Kg}$ & $\begin{array}{l}\text { Lloyd and } \\
\text { Davenport }\end{array}$ & $\begin{array}{c}\text { (Meraz, Oropeza et al. 2002, Meraz, } \\
\text { Domínguez et al. 2003, Abidoye and } \\
\text { Mahdi 2014, Olatunji, Akinlabi et al. 2019) }\end{array}$ \\
\hline & 6 & $\begin{array}{c}\mathrm{HHV}=\left(1-0.1 \mathrm{H}_{2} \mathrm{O}\right) \cdot(-0.3517 \mathrm{C}- \\
1.1625 \mathrm{H}+0.1109 \mathrm{O}-0.0628 \mathrm{~N}- \\
0.1109 \mathrm{~S})\end{array}$ & $\mathrm{MJ} / \mathrm{Kg}$ & Boie & $\begin{array}{l}\text { (Meraz, Oropeza et al. 2002, Meraz, } \\
\text { Domínguez et al. 2003, Abidoye and } \\
\text { Mahdi 2014) }\end{array}$ \\
\hline
\end{tabular}

and without constant) and that depends on the value of VIF and significance

\section{Dry or Free Moisture MSW}

In the first group (dry), multi regression was used with stepwise method (with and without constant approach), the statistical analysis results of the two models are shown in Table 5. The two created models have the same accuracy and all fractions (components) of the solid waste have an impact on the HHV values. The $\mathrm{R}^{2}, \mathrm{~F}$ significance and VIF values were very appropriate statistical tools to form models with high precision.
The two produced models are written as below, the dried fractions must be entered as known in the Table 2, besides the produced HHV is in expressed the $(\mathrm{KJ} / \mathrm{Kg})$. The data that used for verification the obtained models were already excluded from the data that used for building the model(s). Then, Figure 2 and Figure 3 illustrate the relation between the HHV that used for building model(s) and HHV resulted from the verified model (s).

$$
\begin{gathered}
\mathrm{HHV}=163.935 \cdot \mathrm{FO}+364.546 \cdot \mathrm{PL}+ \\
+180.523 \cdot \mathrm{PR}+195.735 \cdot \mathrm{WO}+ \\
+214.180 \cdot \mathrm{TX}
\end{gathered}
$$


Table 5. The Models of Estimation HHV by Dry Fractions of MSW

\begin{tabular}{|c|c|c|c|c|c|c|c|c|}
\hline \multicolumn{5}{|c|}{ Model No.1 } & \multicolumn{4}{|c|}{ Model No.2 } \\
\hline Composition & Beta & VIF & $\mathrm{R}^{2}$ & $\begin{array}{c}\mathrm{F} \\
\text { Significance }\end{array}$ & Beta & VIF & $\mathrm{R}^{2}$ & $\begin{array}{c}\mathrm{F} \\
\text { Significance }\end{array}$ \\
\hline Food (FO) & 163.935 & 6.332 & \multirow{6}{*}{1.0} & \multirow{6}{*}{0.00} & 164.841 & 1.371 & \multirow{6}{*}{1.0} & \multirow{6}{*}{0.00} \\
\hline Plastic (PL) & 364.546 & 3.861 & & & 365.184 & 1.461 & & \\
\hline Paper (PR) & 180.523 & 2.491 & & & 181.155 & 1.501 & & \\
\hline Wood (WO) & 195.735 & 2.437 & & & 196.394 & 1.162 & & \\
\hline Textile (TX) & 214.180 & 2.437 & & & 214.839 & 1.162 & & \\
\hline Constant & ----- & ----- & & & -34.594 & ----- & & \\
\hline
\end{tabular}

$$
\begin{gathered}
\mathrm{HHV}=164.841 \cdot \mathrm{FO}+365.184 \cdot \mathrm{PL}+ \\
+181.155 \cdot \mathrm{PR}+196.394 \cdot \mathrm{WO}+ \\
+214.839 \cdot \mathrm{TX}-34.594
\end{gathered}
$$

\section{Wet MSW (As discarded)}

In this group, the models which result from linear regression with the Enter method, depend on the data shown in Table 3. In addition, the second group of Table 4. Due to the high Variance inflation factor (VIF) of food and moisture content of wet MSW and to avoid high (VIF) in this group, the food water ratio (FWR) was created as a new parameter in the model.

The produced models of these groups were shown in models (3 and 4)

$$
\begin{gathered}
\mathrm{HHV}=329.88 \cdot \mathrm{PL}+152.689 \cdot \mathrm{PR}+ \\
+154.004 \cdot \mathrm{WO}+167.338 \cdot \mathrm{TX}+ \\
+3674.337 \cdot(\mathrm{FO} / \mathrm{M}))-2894.306
\end{gathered}
$$

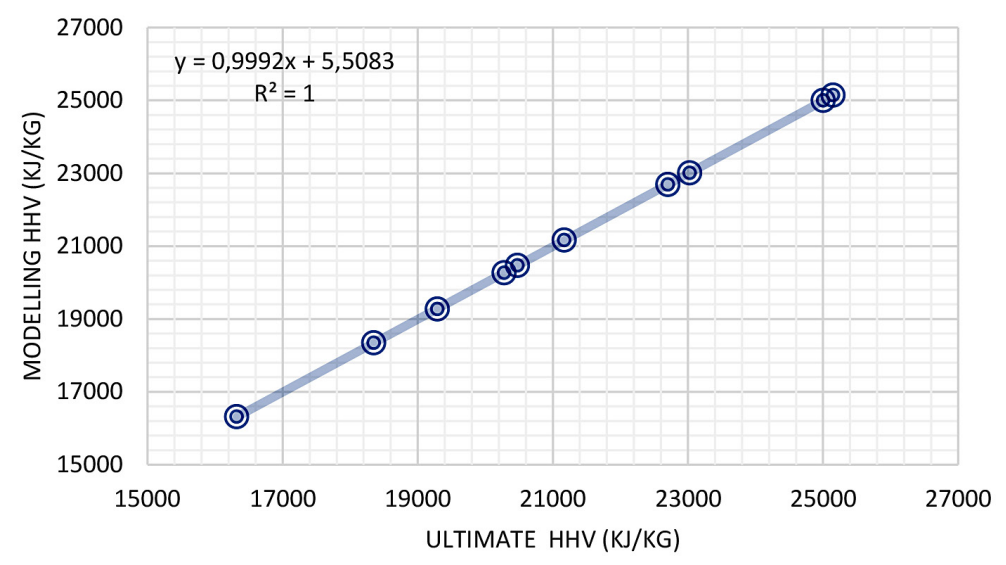

Fig. 2. Verification of Model 1 for the dry MSW

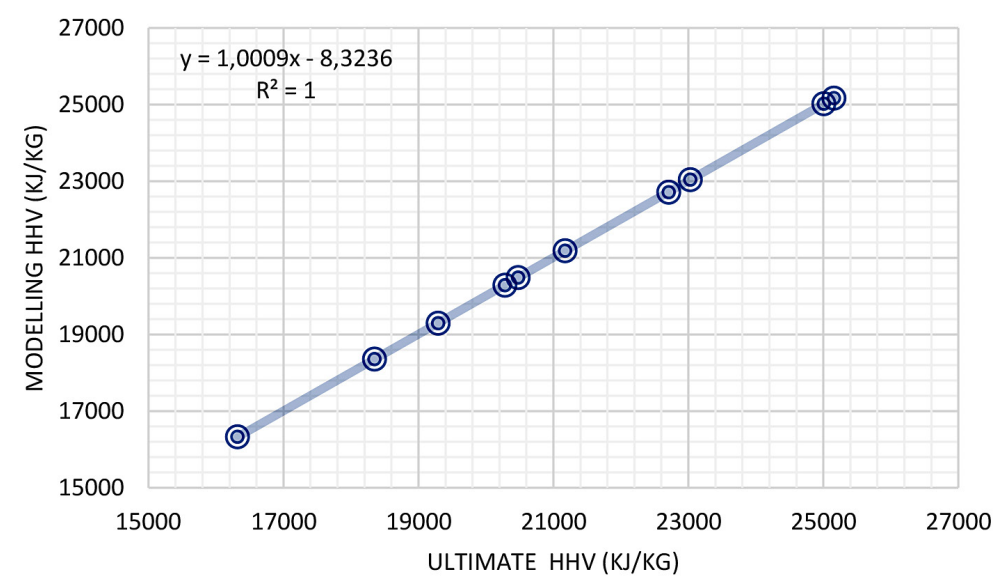

Fig. 3. Verification of Model 2 for the dry MSW 
Table 6. The Models of Estimation HHV by Wet Fractions Of MSW

\begin{tabular}{|c|c|c|c|c|c|c|c|c|}
\hline \multicolumn{5}{|c|}{ Model NO.1 } & \multicolumn{4}{|c|}{ Model NO.2 } \\
\hline Composition & Beta & VIF & $\mathrm{R}^{2}$ & $\begin{array}{c}\mathrm{F} \\
\text { Significance }\end{array}$ & Beta & VIF & $\mathrm{R}^{2}$ & $\begin{array}{c}\mathrm{F} \\
\text { Significance }\end{array}$ \\
\hline Food (FO) & ------ & ----- & \multirow{8}{*}{0.99} & \multirow{8}{*}{0.00} & ---- & ----- & \multirow{8}{*}{0.99} & \multirow{8}{*}{0.00} \\
\hline Plastic (PL) & 329.88 & 1.207 & & & 247.89 & 2.036 & & \\
\hline Paper (PR) & 152.69 & 1.254 & & & 70.30 & 1.995 & & \\
\hline Wood (WO) & 154.01 & 1.088 & & & 71.09 & 1.284 & & \\
\hline Textile (TX) & 167.34 & 1.088 & & & 84.43 & 1.283 & & \\
\hline Constant & -2894.30 & ----- & & & 8411.97 & ----- & & \\
\hline Moisture content (M) & ------- & ----- & & & -101.07 & 2.078 & & \\
\hline $\begin{array}{l}\text { Food / moisture } \\
\text { content (FMR)* }\end{array}$ & 3674.33 & 1.024 & & & ------ & ------ & & \\
\hline
\end{tabular}

* The Ratio of Food to Moisture Content of MSW.

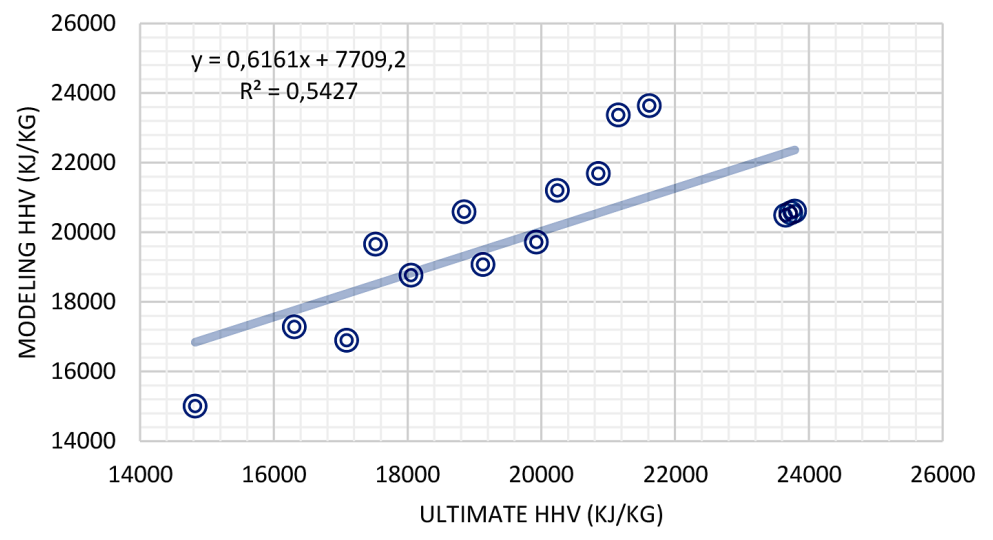

Fig. 4. The Verification of Model 1 for the wet MSW

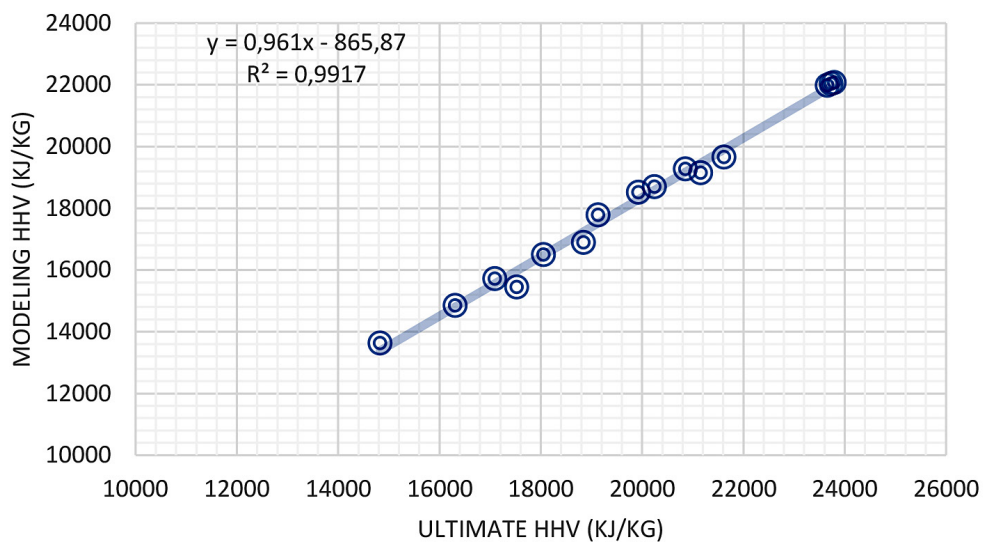

Fig. 5. The Verification of Model 2 for the wet MSW

$$
\begin{gathered}
\mathrm{HHV}=247.892 \cdot \mathrm{PL}+70.306 \cdot \mathrm{PR}+ \\
+71.092 \cdot \mathrm{WO}+84.433 \cdot \mathrm{TX}- \\
-101.071 \cdot \mathrm{M}+8411.970
\end{gathered}
$$

The verification process of the second group showed a weak correlation and difference between the modeling $\mathrm{HHV}$ and the ultimate HHV according to $\mathrm{R}^{2}$ and the equations in Figure 4, while the model 2 showed a difference between the ultimate and modeling $\mathrm{HHV}$ with high $\mathrm{R}^{2}$, as shown in Figure 5.

\section{CONCLUSIONS}

This of research is one of the first kind in Iraq where the disposed MSW was characterized and 
modeled in order to calculate the HHV resulting from these wastes. The following conclusions were drawn from this study:

1. The models in the first group (Dry MSW) were more accurate than those in the second group (Wet MSW).

2. All parameters (major components of the MSW) were appeared in the created models in dry MSW. In turn, with the wet MSW, the models have excluded some parameters.

3. There is no significant difference in the produced models in terms of the physical components for the dry MSW type during the verification processes.

4. For the verification stage, there is a clear difference between the HHV values of the models of wet MSW and those resulting from ultimate analysis by the verification process.

5. Depending on the MSW components in the AL-Diwaniyah city, the produced HHV is $8655 \mathrm{KJ} / \mathrm{Kg}$ from dry MSW and $6440 \mathrm{KJ} / \mathrm{Kg}$ from wet MSW (as received).

The created models in this study can be examined for the estimation of the energy content of the MSW disposed of in other landfills in other cities. Therefore, these models are anticipated to help the decision makers to decide whether setup a landfill gas recovery project and save time, money, space and energy.

\section{REFERENCES}

1. Abbas, M. D., A. M. Falih and K. G. M. Al-Mutawki (2020). A Comparative Study Between Municipal Solid Wastes Management Options in Processing Stage of Al-Diwaniyah city / Iraq. Journal of Physics: Conference Series 1664: 012131.

2. Abdel-Shafy, H. I. and M. S. M. Mansour (2018). Solid waste issue: Sources, composition, disposal, recycling, and valorization. Egyptian Journal of Petroleum 27(4): 1275-1290.

3. Abidoye, L. and F. Mahdi (2014). Novel Linear and Nonlinear Equations for the Higher Heating Values of Municipal Solid Wastes and the Implications of Carbon to Energy Ratios. Journal of Energy Technologies and Policy 4: 14-27.

4. Abu-Qudais, M. d. and H. A. Abu-Qdais (2000). Energy content of municipal solid waste in Jordan and its potential utilization. Energy Conversion and Management 41(9): 983-991.

5. Acikkar, M. and O. Sivrikaya (2018). Prediction of gross calorific value of coal based on proximate analysis using multiple linear regression and artificial neural networks. Turkish Journal Of Electrical Engineering \& Computer Sciences 26: 2541-2552.

6. Akkaya, E. and A. Demir (2009). Energy Content Estimation Of Municipal Solid Waste By Multiple Regression Analysis.

7. Antonopoulos, I., A. Karagiannidis, E. Kalogirou, 2010. Estimation of municipal solid waste heating value in Greece in the frame of formulating appropriate scenarios on waste treatment.

8. Basnayake, B., P. Boyagoda, S. Menikpura and J. Kularatne (2007). Estimations and mathematical model predictions of energy contents of municipal solid waste (MSW) in Kandy.

9. Bousdira, K., L. Nouri, J. Legrand, Y. Bafouloulou, M. Abismail, H. Chekhar and M. Babahani (2014). An overview of the chemical composition of phoenicicole biomass fuel in Guerrara oasis. Proceedings of the 3rd International Symposium on Energy from Biomass and Waste (VENICE 2010), Venice, Italy, CD-ROM edition, 8-11 November (2010).

10. Ch, T., T. Ogwueleka and F. Ogwueleka (2012). Modelling Energy Content Of Municipal Solid Waste Using Artificial Neural Network. Iran. J. Environ. Health. Sci. Eng 7: 259-266.

11. Chai, S. and R. Zakaria (2006). Investigation on combustion characteristics of municipal solid waste from Penang State Malaysia.

12. Chang, Y. F., C. J. Lin, J. M. Chyan, I. M. Chen and J. E. Chang (2007). Multiple regression models for the lower heating value of municipal solid waste in Taiwan. Journal of Environmental Management 85(4): 891-899.

13. Durogbitan, A. A. (2019). Evaluation of Impact of Solid Wastes and Its Potential as A Source of Renewable Energy.

14. A Case Study from Minna and his Environs, Nigeria. Acta Scientific Agriculture 3(5): 145-152.

15. Gidarakos, E., G. Havas and P. Ntzamilis (2006). Municipal solid waste composition determination supporting the integrated solid waste management system in the island of Crete. Waste Management 26(6): 668-679.

16. Group, T. W. B. (2021). Trends in Solid Waste Management." 2021, from https://datatopics.worldbank. org/what-a-waste/trends_in_solid_waste_management.html.

17. Gupta, N., K. K. Yadav and V. Kumar (2015). A review on current status of municipal solid waste management in India. Journal of Environmental Sciences 37: 206-217.

18. Huda, M. (2014). Development of new equations for estimating gross calorific value of Indonesian coals.

19. Ibikunle, R. A., I. F. Titiladunayo, B. O. Akinnuli, S. O. Dahunsi and T. M. A. Olayanju (2019). 
Estimation of power generation from municipal solid wastes: A case Study of Ilorin metropolis, Nigeria. Energy Reports 5: 126-135.

20. Kathiravale, S., M. N. Muhd Yunus, K. Sopian, A. H. Samsuddin and R. A. Rahman (2003). Modeling the heating value of Municipal Solid Waste. Fuel 82(9): 1119-1125.

21. Khuriati, A., W. Budi, M. Nur, I. Istadi and G. Suwoto (2017). Modeling of heating value of municipal solid waste based on ultimate analysis using stepwise multiple linear regression in semarang. ARPN Journal of Engineering and Applied Sciences 12.

22. Khuriati, A., W. Setiabudi, M. Nur and I. Istadi (2015). Heating value prediction for combustible fraction of municipal solid waste in Semarang using backpropagation neural network.

23. Kumar, S., A. N. Mondal, S. A. Gaikwad, S. Devotta and R. N. Singh (2004). "Qualitative assessment of methane emission inventory from municipal solid waste disposal sites: a case study." Atmospheric Environment 38: 4921.

24. Kwaghger, A., Enyejoh, L. A. \& Iortyer, H. A. (2017). The development of equations for estimating high heating values from proximate and ultimate analysis for some selected indigenous fuel woods.

25. Leme, M. M. V., M. H. Rocha, E. E. S. Lora, O. J. Venturini, B. M. Lopes and C. H. Ferreira (2014). Techno-economic analysis and environmental impact assessment of energy recovery from Municipal Solid Waste (MSW) in Brazil. Resources, Conservation and Recycling 87: 8-20.

26. Lin, X., F. Wang, Y. Chi, Q. Huang and J. Yan (2015). A simple method for predicting the lower heating value of municipal solid waste in China based on wet physical composition. Waste Management 36: 24-32.

27. Liu, J. I., R. D. Paode and T. M. Holsen (1996). Modeling the Energy Content of Municipal Solid Waste Using Multiple Regression Analysis. J Air Waste Manag Assoc 46(7): 650-656.

28. Lopes, E. J., L. A. Okamura and C. I. Yamamoto (2015). Formation of dioxins and furans during municipal solid waste gasification. Brazilian Journal of Chemical Engineering 32: 87-97.

29. Meraz, L., A. Domínguez, I. Kornhauser and F. Rojas (2003). A thermochemical concept-based equation to estimate waste combustion enthalpy from elemental composition. Fuel 82(12): 1499-1507.

30. Meraz, L., M. Oropeza and A. Dominguez (2002). Prediction of the Combustion Enthalpy of Municipal Solid Waste. The Chemical Educator 7(2): 66-70.

31. Nagarajan, R., S. T and E. Lakshmanan (2010). Groundwater Contamination due to municipal solid waste disposal - A GIS based study in Erode city. International Journal of Environmental Sciences 1: $39-55$.

32. Nzihou, J., S. Hamidou, M. Bouda, J. Koulidiati and B. Segda (2014). Using Dulong and Vandralek Formulas to Estimate the Calorific Heating Value of a Household Waste Model.

33. Olatunji, O., S. Akinlabi, N. Madushele and P. Adedeji (2019). Estimation of Municipal Solid Waste (MSW) combustion enthalpy for energy recovery. EAI Endorsed Transactions on Energy Web 6.

34. Olatunji, O., S. Akinlabi, N. Madushele, P. Adedeji and F. Ishola (2019). Multilayer perceptron artificial neural network for the prediction of heating value of municipal solid waste. AIMS Energy 7: 944-956.

35. Omari, A. (2015). Characterization of Municipal solid waste for energy recovery. A case study of Arusha , Tanzania.

36. Ryu, C. (2010). Potential of Municipal Solid Waste for Renewable Energy Production and Reduction of Greenhouse Gas Emissions in South Korea. Journal of the Air \& Waste Management Association 60(2): 176-183.

37. Scarlat, N., V. Motola, J. F. Dallemand, F. MonfortiFerrario and L. Mofor (2015). Evaluation of energy potential of Municipal Solid Waste from African urban areas. Renewable and Sustainable Energy Reviews 50: 1269-1286.

38. Siddiqui, F. Z., S. Zaidi, S. Manuja, S. Pandey and M. E. Khan (2017). Development of models for prediction of the energy content of disposed MSW from an unsecured landfill. Waste Manag Res 35(11): 1129-1136.

39. Zhou, H., A. Meng, Y. Long, Q. Li and Y. Zhang (2014). Classification and comparison of municipal solid waste based on thermochemical characteristics. Journal of the Air \& Waste Management Association 64(5): 597-616. 